Панченко Олег Анатолійович доктор медичних наук, доктор 3 державного управління, професор, президент ГО «Всеукраїнська професійна психіатрична ліга», Заслужений лікар України, головний науковий співробітник, директор ДЗ «Науково-практичний медичний реабілітаційнодіагностичний центр МО3 України», вул. Ол. Невського, 14, м. Костянтинівка, 85110, тел.: (050) 900-00-07, e-mail: oap@ukr.net, https://orcid.org/0000-0001-9673-6685

Антонов Віктор Григорович начальник адміністративноінформаційного відділу, молодший науковий співробітник ДЗ «Науковопрактичний медичний реабілітаційно-діагностичний центр МОЗ України», вул. Ол. Невського, 14, м. Костянтинівка, 85110, тел.: (099) 057-40-03, e-mail: avg2001@ukr.net, https://orcid.org/0000-0003-0146-9786

\title{
ДЕЗІНФОРМАЦІЯ В СУЧАСНИХ СОЦІО-КУЛЬТУРНИХ УМОВАХ ІНФОРМАЦІЙНОЇ ЕКОСИСТЕМИ
}

Анотація. У статті досліджуються тенденції поширення дезінформації та концепції щодо протидії і запобіганню дезінформації в сучасних соціокультурних умовах інформаційної екосистеми. Остання має на увазі методологію досліджень інформаційного середовища як цілої (системної) частини навколишнього середовища. В інформаційній екосистемі інформація все більшою мірою передається через цифрові пристрої і соціальні мережі. Дезінформація (брехлива інформація, яка навмисно створюється або поширюється з явною метою завдати шкоди), що перманентно розширюється і приймає все більш загрозливі форми, є однією з головних проблем інформаційної екосистеми.

Дезінформація досліджена у трьох аспектах інформаційного контенту: види; мотивації створення; способи поширення. Виявлено сім різних видів проблемного контенту (сатира або пародія; той, що вводить в оману; самозванець; сфабрикований; хибне з'єднання; фальшивий; маніпулятивний), три мотивації (політична, фінансова, соціально-психологічна). Щодо способів поширення акцентовано, що ієрархічні інформаційні структури все більш витісняються мережевими, а ті що ще залишаються трансформуються до більшого наповнення емоційним контентом.

Розглянуте поняття Truth Decay (розпад правди), де виділено чотири характерні ознаки: посилення розбіжностей відносно фактів i даних; стирання межі між думкою і фактом; збільшення відносного обсягу думок в порівнянні з фактами; зниження довіри до інституцій, які раніше вважалися авторитетними джерелами фактичної інформації. 
В плані протидії дезінформації наголошено про актуальність організаційних, політико-правових та технічних заходів. Розглянуто досвід зарубіжжя та заходи, що потрібно здійснити державі. Увагу акцентовано насамперед на наступному:

- здійснення системних заходів, спрямованих на посилення можливостей державних інституцій для забезпечення інформаційної безпеки, виявлення і протидії дезінформації;

- вдосконалення системи правового та наукового забезпечення інформаційної безпеки, виявлення і протидії дезінформації;

- покращення взаємодії держави та інституцій громадянського суспільства щодо протидії дезінформації та деструктивним інформаційним явищам;

- інформаційно-просвітницькі заходи 3 питань підвищення медіаграмотності суспільства.

Ключові слова: інформаційна екосистема, інформаційна безпека, дезінформація, проблемний контент, емоційний контент, розпад правди, постправда.

Panchenko Oleg Anatoliyovych Doctor of Medical, Doctor of State Administration, Professor, President of the All-Ukrainian Professional Psychiatric League, Honored DoScientist of Ukraine, Chief Scientist of Science, Director of the Educational-Ukrainian Center for Medical Sciences region, Ol. Nevsky St., 14, Kostyantinivka, 85110, tel.: (050) 900-00-07, e-mail: oap@ukr.net, https://orcid.org/0000-0001-9673-6685

Antonov Viktor Grigorovich Head of the Administrative and Information Department, Young Scientist of the Scientific Practical Medical Rehabilitation Center of the Ministry of Health of Ukraine, Ol. Nevsky, 14, Kostyantinivka, 85110, tel.: (099) 057-40-03, e-mail: avg2001@ukr.net, https://orcid.org/00000003-0146-9786

\section{DISINFORMATION IN MODERN SOCIO-CULTURAL CONDITIONS OF THE INFORMATION ECOSYSTEM}

Abstract. The trends of disinformation and the concept of both counteracting and preventing misinformation in the modern socio-cultural conditions of the information ecosystem are investigated herein. The information ecosystem implies the methodology of the study of the information environment as a whole (systemic) part of the environment. The information in it is increasingly transmitted through digital devices and social networks. Disinformation (false information that is intentionally created or disseminated for the obvious purpose of harming), which is constantly expanding and taking on increasingly threatening forms, is one of the main issues of the information ecosystem. 
Disinformation is studied in three aspects of information content, namely: types; motivation to create; ways of distribution. Seven different types of problematic content (satire or parody; misleading; impostor; fabricated; false connection; fake; manipulative), three motivations (political, financial, sociopsychological) were identified. It is emphasized that regarding the methods of dissemination, hierarchical information structures are increasingly being replaced by network ones, and those that remain are being transformed to a higher filling with emotional content.

The concept of Truth Decay is considered, where four main features are underlined, namely: strengthening of discrepancies in respect of the facts and data; blurring the line between thought and fact; increase in the relative volume of opinions in comparison with the facts; declining confidence in institutions that were previously considered authoritative sources of the facts.

In terms of counteracting disinformation, the urgency of organizational, political, legal, and technical measures was emphasized. The experience of foreign countries and measures to be taken by the state are considered. Attention is focused primarily on the following:

- implementation of systematic measures aimed at strengthening the capacity of state institutions to ensure information security, detection, and counteraction of disinformation;

- improving the system of legal and scientific support of information security, detection, and counteraction of misinformation;

- improving the interaction between the state and civil society institutions in combating disinformation and destructive information phenomena;

- informational and educational activities to increase media literacy of society.

Keywords: information ecosystem, information security, disinformation, problem content, emotional content, truth decay, post-truth.

Постановка проблеми. Стрімке зростання значення інформації в житті суспільства актуалізує проблему розпізнавання брехливого і шкідливого контенту в інформаційних потоках. З'явилося ряд понять, які використовуються для пояснення деструктивних процесів, що відбуваються в інформаційному середовищі: «інформаційний хаос», «інформаційний безлад», «інформаційне забруднення», «інформаційний шум» і ін. Масштаб i складність дезінформації в цих процесах представляє безпрецедентну проблему.

Бурхливий розвиток Інтернету призвів до появи мережевих засобів масової інформації (ЗМI), трансформацією їх в засоби масового спілкування (3МС), які за рядом показників випереджають традиційні, стрімко розширюють свою цільову аудиторію, а в умовах прискореного темпу життя поступово стають пріоритетними і достатніми для все більшого числа людей. Дезінформація, що $є$ невід'ємною частиною контенту, розповсюджуваного в ЗМІ і ЗМС, - проблема, що стосується безлічі соціальних, економічних, культурних, технологічних і політичних процесів, яка не може бути вирішена 
спрощено. Визнаючи вплив таких чинників як крах теорії держави загального добробуту, нездатність демократичних інститутів в наданні суспільних послуг, зміна клімату та епідеміологічної обстановки, іноземні втручання, не можна розглядати феномен дезінформації в ізоляції - необхідно враховувати його вплив у глобальній інформаційній екосистемі.

Таким чином, осмислення помилкової i шкідливою інформації як загрози для держави, суспільства, людини, дослідження технології продукування i поширення дезінформації, а також шляхів мінімізації іï деструктивних наслідків, є актуальним завданням.

Аналіз останніх досліджень і піблікацій. Дослідженню дезінформації в останній час приділяється значна увага з боку науковців (Bob Holmes[9], Claire Wardle [10,11], Георгій Почепцов [6], Колісник О. Л [3] та інш.). Дезінформація розглядається 3 різних сторін, в тому числі як соціальна хвороба, до якої можна застосовувати епідеміологічний підхід, що вивчає те, як і чому вона стрімко поширюється між людьми. Наголошується, що хоча неправдива інформація і не нове явище, поява Інтернету і соціальних мереж призвела до фундаментальних змін в способах виробництва і поширення такої інформації. Підкреслюється, що:

a) 3 появою широкодоступних, дешевих сучасних технологій редагування і публікації стало простіше, ніж коли-небудь, створювати i поширювати контент;

б) споживання інформації, яке колись було приватним, стало публічним через соціальні медіа;

с) швидкість поширення інформації збільшена за рахунок прискореного циклу новин і мобільних телефонів;

г) інформація передається в режимі реального часу між довіреними вузлами і набагато рідше піддається сумніву.

Дезінформація вивчається державними установами (наприклад, звіт Комітету 3 цифрових технологій, культури, ЗМІ та спорту Британського парламенту, 2019 [12]), аналітичними центрами (наприклад, RAND Corporation («Research ANd Development») [8,18]). У 2018 році Єврокомісія презентувала «Кодекс практики Свропейського Союзу 3 протидії дезінформації» [15].

В Україні стоврений спеціальний Центр протидії дезінформації, завданням якого $\epsilon$ «здійснення заходів щодо протидії поточним i прогнозованим загрозам національній безпеці та національним інтересам України в інформаційній сфері, забезпечення інформаційної безпеки України, виявлення та протидії дезінформації, ефективної протидії пропаганді, деструктивним інформаційним впливам і кампаніям, запобігання спробам маніпулювання громадською думкою» [7].

3 наведеного матеріалу випливає, що проблема дезінформації потребує глибокого системного осмислення. 
Мета статті. Дослідити тенденції поширення дезінформації та концепції щодо протидії і запобіганню дезінформації в сучасних соціокультурних умовах інформаційної екосистеми.

Виклад основного матеріалу. В даному дослідженні спеціально задіяно поняття «екосистема» - в проекції на інформаційне середовище воно підкреслює системність процесів, що відбуваються. Цифрові екосистемні моделі засновані на природних екосистемах, особливо вони схожі щодо аспектів, пов'язаних з конкуренцією і співпрацею між різними суб'єктами. Внаслідок цього і з'явився термін «екологічний підхід», що має на увазі, зокрема, методологію досліджень інформаційного середовища як цілої (системної) частини навколишнього середовища, що розглядається в формі екосистеми.

В інформаційній екосистемі інформація всі більшою мірою передається через цифрові пристрої і соціальні мережі. Дані американських дослідників [13] свідчать, що понад вісім 3 десяти дорослих американців (86\%) отримують новини зі смартфона, комп'ютера або планшета «часто» або «іноді». Близько двох третин дорослого населення США кажуть, що вони хоча б іноді отримують інформацію із новинних сайтів (68\%) або пошукових систем, таких як Google (65\%). Близько половини (53\%) кажуть, що вони отримують новини 3 соціальних мереж. Актуальної інформації щодо української аудиторії немає, але тенденція, за нашими спостереженнями, відповідає світовій.

У цих умовах актуалізується і набуває перманентно загрозливої форми таке явище як дезінформація. В загальному визначенні дезінформація брехлива інформація, яка навмисно створюється або поширюється 3 явною метою завдати шкоди. У Кодексі практики Свропейського Союзу з протидії дезінформації наводиться таке визначення: «напевно неправдива або така, яка вводить в оману, інформація, що в сукупності: а) створена, представлена і поширена $з$ метою економічної вигоди або умисного введення в оману громадськості; б) може заподіяти шкоду суспільству через загрозу демократичним політичним процесам і процесам вироблення політики, а також таким суспільним благам, як захист здоров'я громадян, довкілля $\mathrm{i}$ безпеки».

Слід підкреслити відмінність дезінформації від фейку - недостовірна інформація у випадку останнього може бути випадковою, а дезінформація свідоме введення в оману. Наприклад, у звіті Комітету 3 цифрових технологій, культури, ЗМІ та спорту Британського парламенту зазначено, що назву проведеного Комітетом розслідування було свідомо змінено 3 «фейкових новин» на «дезінформацію і фейкові новини», оскільки останні використовуються для опису контенту, який може не сподобатися читачеві, або він може з ним не погодитися, тоді як «дезінформація» використовується при свідомому створенні і розповсюдженні фальшивої і / або маніпуляційної інформації, призначеної для обману і введення в оману аудиторії для цілей 
нанесення шкоди, або для отримання політичних, особистих або фінансових переваг.

Головна небезпека дезінформації полягає в тому, що в умовах інформаційної і соціально-політичної турбулентності, про яку все частіше говорять дослідники [14], вона може викликати несподівані деструктивні чинники. Відомо, що у теорії хаосу одним 3 основних властивостей динамічної системи є чутливість до початкових умов, яка зазвичай згадується як «ефект метелика». Невеликі відмінності у початкових умовах приводять до результатів, що значно відрізняються. Звідси довгострокове передбачення практично неможливе. Дезінформація в певних умовах може стати «метеликом», який призведе до соціально-політичного вибуху 3 непередбачуваними наслідками.

Для пояснення суті дезінформації розглянемо три аспекти контенту в інформаційній екосистемі: А) види; Б) мотивації створення; С) способи поширення.

А). На сьогоднішній день можна виділити сім різних видів проблемного контенту.

1. Сатира або пародія - форма мистецтва, яка може стати дезінформацією, коли аудиторія невірно інтерпретує повідомлення, не розуміючи, що сайт або окрема колонка новинного сайту є сатиричними.

2. Контент, що вводить в оману - використання інформації для неправильного відображення проблеми або особистості. Цей тип контенту пов'язаний з сегментуванням проблеми і передбачає погляд на людину або подію під певним кутом зору - через обрізання фотографій, вибіркове використання цитат, статистики тощо.

3. Самовільний контент (контент-самозванець) - справжнє джерело не персоніфіковане. Наприклад, коли статті підписуються іменами, які не є їх авторами, або у відео чи зображення включаються назви чи логотипи організацій, які непричетні до їх створення.

4. Сфабрикований контент - на 100\% фальшивий, призначений для обману і заподіяння шкоди. Новітні технології дозволяють швидко виробляти фальшиві аудіо- та відеоматеріали, видаючи їх за справжні (наприклад, використовуючи дипфейк - новий формат відеороликів, в яких особи одних людей замінюються іншими) для створення враження, що конкретна людина сказала або зробила щось у певному місці.

5. Хибне з'єднання (помилковий зв'язок) - заголовки, візуальні ефекти або підписи не відображають зміст. Найбільш поширеним прикладом такого типу є клікбейт (англ. clickbait від click «клацання» + bait «приманка»), мета якого - спонукати користувача до здійснення необхідної дії.

6. Фальшивий (брехливий) контекст - справжній контент передається 3 вмонтованою контекстною інформацією, яка може бути справжньою в якомусь іншому повідомленні, репортажі, відео, але спеціально вирвана із початкового для спотворення правдивого контенту.

7. Маніпулятивний контент - створюється 3 метою відволікання уваги від інформативного складника повідомлення й апеляції до емоційного. Серед 
технологій поширеними $\epsilon$ : фрагментарний спосіб подачі інформації, додавання в матеріал неперевіреної інформації, приховування інформації, селекція інформації, «інформаційний шум», репрезентація тільки однієї точки зору як єдино правильної.

Самий «успішний» проблемний контент - той, що грає на емоціях людей, збуджуючи відчуття переваги, гніву або страху. Коли більшість соціальних платформ створені для того, щоб люди публічно «виступали» через лайки, коментарі або публікації, легко зрозуміти, чому емоційний контент поширюється так швидко i широко. Сьогодні кожен власник профілю в соціальній мережі є не тільки посередником у передачі інформації, але і власне творцем інформації. Надаючи контенту «свою версію», медіум (посередник в ланцюжку комунікацій) свідомо чи несвідомо включає механізми нейропсихології, програмуючи реакцію цільової аудиторії.

«Емоційний контент» все частіше пов'язують 3 явищем, яке отримало назву «постправда» - обставини, в яких об'єктивні факти менш важливі для формування громадської думки, ніж звернення до емоцій i особистим переконанням. Основні прийоми постправди :

- спотворення, приховування, обман (повідомляється тільки частина фактів, виставляється вперед лише позитивна або негативна сторона, а решта приховується);

- використання емоцій i індивідуалізму (маніпулювання емоційним сприйняттям інформації через призму контексту, згущення фарб, можливістю під себе фільтрувати контент і т.п.);

- використання ліні і відсутності часу на перевірку достовірності (цейтнот, небажання або невміння перевіряти факти);

- розмовний стиль, емоційно забарвлена лексика, метафоричність, гумор;

- обсяг і тиражування.

Б). Знання мотивацій створення несумлінного контенту дозволяє виявити технології дезінформації та визначити можливі способи протидії.

Політичні мотивації. Виробництво дезінформаційного контенту в політичній площині потрапляє в нову форму протиборства під назвою «гібридна війна» - приховані агресивні дії, що йдуть врозріз 3 нормами міжнародного права. Російський підхід військової науки до гібридної війні відображений в «Доктрині Герасимова» [1,17], де акцент використовуваних методів протиборства зміщується в бік широкого застосування політичних, економічних, інформаційних, гуманітарних та інших невійськових заходів, реалізованих із задіянням протестного потенціалу населення.

Інформаційна і соціально-політична турбулентність ускладнює і без того непросту обстановку в боротьбі як за світовий, так і внутрішньодержавний ідеологічний впливи, коли зустрічні потоки дезінформації, перемішуючись, створюють хаос і плутанину в головах людей.

Компанія Facebook у травні цього року оприлюднила звіт за 4 роки, у якому розглядаються загрози операцій з впливу та так звана «скоординована неавтентична поведінка» [19]. Facebook заявляє, що 32017 року вона 
виявила кампанії з дезінформації в більш ніж 50 країнах. Звіт підсумовує 150 операцій 3 дезінформації. В цілому, згідно 3 аналізом, Україна, як постачальник дезінформації займає п’яте місце у світі, а серед країн, які найчастіше зазнавали іноземних операцій 3 дезінформації - друге. Відзначимо, що раніше цього місяця Facebook видалив 105 облікових записів, 24 сторінки і п'ять профілів Instagram, керованих з України. Акаунти видалили за порушення політики Facebook щодо скоординованої неавтентичної поведінки [2], Операції з дезінформації були направлені як на зовнішню, так і внутрішню аудиторію.

Фінансові мотиващії. Субєкти, що виробляють або поширюють дезінформацію, можуть робити це просто заради фінансової вигоди. Широко відомий феномен англомовних веб-сайтів, створених «македонськими школярами», які використали ентузіазм американських читачів щодо сенсаційних історій. Молоді програмісти, які живуть в Велесі - місті в центрі Македонії з населенням в 44 тисячі чоловік, вирішили заробити на виборах президента США в 2016 році. Один 3 творців веб-сайтів в підтримку кандидата-республіканця, повідомив, що його сторінка в Мережі отримує щомісячний дохід в розмірі від 600 до 1000 євро [4]. Програміст не приховує, що частина опублікованих матеріалів містить невірну інформацію, а крикливі заголовки мають на меті залучити якомога більше читачів.

Сайти «фейковий новин» заробляють гроші і на рекламі «брендових» кампаній (технологічні компанії, банки, роздрібні торговці, авіакомпанії, косметика, предмети розкоші, університети і т.д.). Frederic Filloux у своєму дослідженні, посилаючись на дані французької фірми Storyzy, що спеціалізується на виявленні неправдивої інформації в мережі, у серпні 2017 року звернув увагу на те, що понад 600 брендів розміщували рекламу на сумнівних сайтах - від сайтів 3 жорсткими фальшивими новинами до клікбейтінгових майданчиків, на яких розміщується фіктивний контент без будь-якої конкретної мети, за винятком швидкого заробітку [16].

Ще один вид заробітку, коли дезінформаційні матеріали виробляються за контрактом 3 політичними або комерційними суб'єктами контенту. Популярні блогери, інстаграм- «інфлюенсери» і зірки YouTube просувають продукти і політиків, не вказуючи, що їм платять за це. Приховані платежі отримують також коментатори (часто з брехливою ідентифікацією), які спотворюють інформацію, займаються дискредитацією або залякуванням.

Соціально-психологічні мотивації. В даному контексті дезінформацію можна розглядати як один 3 видів інформаційно-психологічного впливу особливої форми прояви соціальної активності індивідуального або групового суб'єкту в рамках комунікативного простору, що полягає в цілеспрямованому направленні спеціально підібраної інформації, в результаті чого з боку об'єкту впливу формується психоемоційний відгук, що приводить до зміни характеру сприймаємої ним інформації, і в результаті корегування його індивідуальної картини світу в потрібному суб'єкту впливу ключі. Колесник О. Л., говорячи про дезінформацію в міжособистісному спілкуванні, підкреслює, що в житті мають місце випадки, коли людина 
хотіла б, але не може говорити правду. Зустрічаються як спонтанна, так i ретельно підготовлена брехня. Буває брехня, яка викликає у іiі автора почуття сорому, або, навпаки, почуття гордості за себе і т.П. Причиною брехні виступає якийсь мотив, безпосередня реалізація якого в даній ситуації без допомоги дезінформування партнера представляється брехуну ускладненою або взагалі неможливою. Додамо до цієї думки, що породження дезінформації залежить не тільки від усвідомлення індивідом іiі суб'єктивної необхідності. Важливе значення мають соціальні, соціально-психологічні та інші умови безпосереднього спілкування 3 потенційним об'єктом дезінформування і поведінку останнього в даній ситуації: в одних випадках воно стимулює, в інших - перешкоджає виникненню дезінформації.

С. Сучасна інформаційна екосистема відрізняється тим, що ієрархічні інформаційні структури все більш витісняються мережевими. Як зазначає Георгій Почепцов, «ми живемо у світі, в якому фізичний, інформаційний і віртуальний простір перетинаються набагато інтенсивніше, ніж це було раніше. Інформаційний простір, посилений соціальними мережами, починає домінувати над простором фізичним і часто над віртуальним, оскільки будьяке інформаційне повідомлення збудоване під ту чи іншу віртуальну позицію і тим самим поширює їі, навіть не акцентуючи». Ті традиційні інформаційні структури, які ще залишилися, зазнали суттєвих змін. На основі досліджень RAND Corporation i власних спостережень в табл.1 проілюстровано їх трансформацію в певному проміжку часу.

Таблиия 1

Трансформація джерел інформації у часовому інтервалі

\begin{tabular}{|c|c|c|}
\hline Джерело & \multicolumn{2}{|c|}{ Варіанти } \\
\hline Газетна журналістика & 2000 рік & 2021 рік \\
\hline & $\begin{array}{c}\text { Репортаж на основі } \\
\text { контексту і подій, } \\
\text { заснованих на директивах, } \\
\text { використанні звань і } \\
\text { службових посад, апеляції } \\
\text { до влади } \\
\end{array}$ & $\begin{array}{c}\text { Розповідний стиль } 3 \\
\text { великою кількістю } \\
\text { оповідань і звернень до } \\
\text { емоцій }\end{array}$ \\
\hline \multirow[t]{2}{*}{ Ефірне телебачення } & 2000 рік & 2021 рік \\
\hline & $\begin{array}{c}\text { Академічний стиль, } \\
\text { використання чисел, } \\
\text { абстрактних міркувань і } \\
\text { аргументів, чітка мова }\end{array}$ & $\begin{array}{c}\text { Розмовний тон, більш } \\
\text { особиста точка зору і } \\
\text { суб'єктивність }\end{array}$ \\
\hline \multirow{2}{*}{$\begin{array}{c}\text { Ефірне vs кабельне } \\
\text { телебачення, 2000-2021 }\end{array}$} & Ефірне & Кабельне \\
\hline & $\begin{array}{c}\text { Детальні описи подій, } \\
\text { людей, матеріального } \\
\text { світу; соціальна дистанція }\end{array}$ & $\begin{array}{c}\text { Надмірно інтерактивна і } \\
\text { суб'єктивна аргументація } \\
\text { й імперативи, спрямовані } \\
\text { на переконання і дебати }\end{array}$ \\
\hline $\begin{array}{c}\text { Печатна vs онлайн } \\
\text { журналістика, 2012- }\end{array}$ & Печатна & Онлайн \\
\hline
\end{tabular}




\begin{tabular}{|c|c|c|}
\hline 2021 & $\begin{array}{c}\text { Акцентований характер } \\
\text { і наратив з особливою } \\
\text { увагою до контексту, } \\
\text { послідовності, подіям }\end{array}$ & $\begin{array}{c}\text { Особиста і суб'єктивна, } \\
\text { інтерактивна, акцентована } \\
\text { аргументація і захист, } \\
\text { наполеглива мова, } \\
\text { узагальнення }\end{array}$ \\
\hline Viber Messenger & 2010 рік & 2021 рік \\
\hline & $\begin{array}{c}\text { Двосторонній телефонний } \\
\text { зв'язок через Інтернет; } \\
\text { обмін інформацією }\end{array}$ & $\begin{array}{c}\text { Джерело новин; соціальна } \\
\text { мережа; групові відеочати, } \\
\text { спільноти за інтересами }\end{array}$ \\
\hline \multicolumn{2}{|c|}{}
\end{tabular}

На основі наведених даних можна стверджувати, що з часом і в міру того, як суспільство перейшло від «старих» до «новим» ЗМІ, новинний контент перемістився від більш об'єктивного висвітлення подій і контексту до репортажів, які є більш суб'єктивними, в більшій мірі спираються на аргументацію і включають більш емоційні посили.

Аналізуючи проблему дезінформації, RAND ввела поняття Truth Decay (розпад правди), коли зменшується роль фактів, даних i аналізу в політичному і цивільному дискурсі. Поняття розглядається як система 3 прямими i зворотними зв'язками. В нашій інтерпретації Truth Decay представлена на рис.1. Аналіз рисунку дозволяе стверджувати, що Truth Decay є загрозою демократії, політиці, і самому громадянському дискурсу, призводячи до хаотизаціііі і невизначеності. $\mathcal{C}$ підстави вважати, що дане явище притаманне i українському суспільству. А, отже, необхідні першочергові кроки для пошуку рішень вказаної проблеми. Виходячи 3 аналізу рушійних факторів на рис.1., це можуть бути наступні.

Освітні заходи, що включають: оновлення освіти; задіяння більш досконалих інструментів для підтримки медіаграмотності.

Відновлення суспільної довіри до інститутів влади. Це потребує ряду реформ, в тому числі тих, які спрямовані на забезпечення прозорості державного управління, залучення і створення загального національного досвіду для оновлення соціальної інфраструктури. 


\section{РУШІЙНІ ФАКТОРИ}

Зміни в інформаційному середовищі: трансформація суспільних медіа; Інтернет і соціальні мережі; розповсюдження

Поляризація: політична; економічна; соціодемографічна

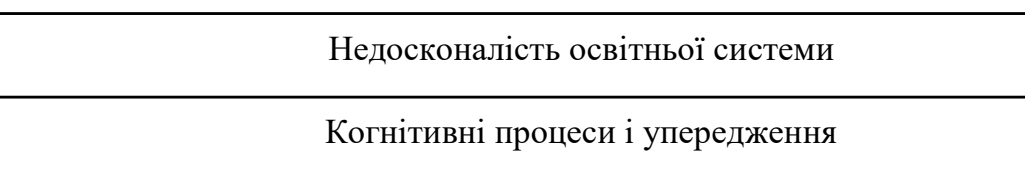

\section{АГЕТИ РОЗПАДУ ПРАВДИ}

Медіа

Академічні і дослідницькі організації

Політичні актори і уряд

Іноземні актори

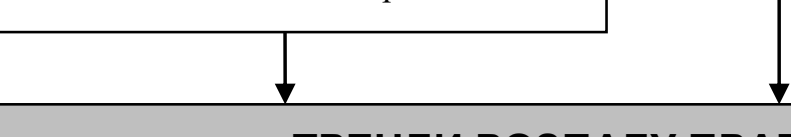

\section{ТРЕНДИ РОЗПАДУ ПРАВДИ}

Зростання розбіжностей щодо фактів і даних

Стирання межі між думкою і фактом

Збільшення обсягу думок стосовно фактів

Зниження довіри до авторитетних джерел інформації

\begin{tabular}{|c|}
\hline НАСЛІДКИ \\
\hline Ерозія громадянського дискурсу \\
\hline Політичний параліч \\
\hline Відчуження і роз'єднання \\
\hline Невизначеність \\
\hline
\end{tabular}

\section{Puc.1. Truth Decay як система}

Зміни в способах поширення інформації, в тому числі і в журналістиці, яка краще розділяе факти і думки, а також в більш доступній науковій комунікації.

Розробка і вдосконалення інструментів $і$ механізмів управління для боротьби з поширенням дезінформації в Інтернеті. Це потребує в першу чергу визначення та зосередження в одному місці набору ресурсів та інструментів, які можуть допомогти користувачам боротися 3 проблемою дезінформації, краще зрозуміти екосистему ЗMI i стати більш 
кваліфікованими споживачами засобів масової інформації. Важливим також є інформування про набір інструментів, які в даний час актуалізуються, i які потребують фінансування, а також про розроблені інструменти, які можуть послужити внеском у зусилля по створенню поля навколо вивчення дезінформації і засобів захисту від неї.

Інструменти, спрямовані проти дезінформації, виступають в самих різних формах - від веб-сайтів, що працюють на основі перевірок фактів, до додатків, що використовують штучний інтелект для виявлення ботів. На сьогодні можна виділити кілька категорій.

I. Норми i стандарти - відносяться до всіх інструментів, які встановлюють нові принципи або передовий досвід для управління набором процесів або для керівництва поведінкою. У більшості - це документи, спрямовані на захист від дезінформації, підвищення якості журналістики або на примус окремих осіб або компаній до встановлених правил.

II. Виявлення ботів / спаму - інструменти призначені для ідентифікації автоматичних облікових записів на платформах соціальних мереж.

III. Оцінка достовірності - інструменти видають рейтинг або оцінку окремим джерелам на основі їх точності, прозорості, якості та інших показників надійності.

IV. Відстеження дезінформації - інструменти відстежують і / або вивчають потоки і поширеність дезінформації.

V. Освіта / навчання - інтерактивні курси, ігри та заходи, спрямовані на боротьбу з дезінформацією шляхом навчання людей новим навичкам або концепціям.

VI. Перевірка фактів - інструменти, що встановлюють точність інформації або справжність фотографій, відео.

VII. Білий список - ці інструменти створюють надійні списки IP-адресів або веб-сайтів щоб розрізняти надійні джерела від тих, які можуть бути підробленими або шкідливими.

Даний перелік інструментів є далеко не повним, і може стати предметом вивчення і доповнення для нового державного органу - «Центру протидії дезінформації».

Висновки. Тенденції все більш прискореного розвитку явища дезінформації в сучасних соціо-культурних умовах інформаційної екосистеми потребують багатогранних i міждисциплінарних зусиль зі сторони дослідницьких інститутів, політиків, технологічних компаній, засобів масової інформації, викладачів і окремих осіб щодо вирішення цієї актуальної проблематики.

В плані протидії дезінформації необхідно задіяти широкий спектр організаційних, політико-правових та технічних заходів 3 урахуванням досвіду зарубіжжя. Увагу слід зосередити насамперед на наступному: здійснення системних заходів, спрямованих на посилення можливостей державних інститутуцій щодо виявлення i протидії дезінформації; вдосконалення системи правового та наукового забезпечення виявлення i протидії дезінформації; покращення взаємодії держави та інститутів 
громадянського суспільства щодо протидії дезінформації; інформаційнопросвітницькі заходи з питань підвищення медіа-грамотності суспільства.

\section{Jimepamypa:}

1. Герасимов В.В. Ценность науки в предвидении. Военно-промышленный курьер. 2013. № 8(476). URL: https://www.vpk-news.ru/articles/14632 (дата звернення: 20.05.2021).

2. Сврокомісія презентувала кодекс протидії фейкам. УКРІНФОРМ.

29.01.2019. URL: https://www.ukrinform.ua/rubric-world/2629474-evrokomisiaprezentuvala-kodeks-protidii-fejkam.html (дата звернення: 20.05.2021).

3. Колісник О.Л., Плохута І.С., Третяк С.Д. Соціально-психологічні та феноменологічні аспекти дослідження проблеми дезінформації у міжособистісному спілкуванні. Вісник Національного університету оборони України 1 (59) /2021. С.121-130. DOI: $10.33099 / 2617-6858-21-59-1-121-130$

4. Михаил Бушуев. Как предприимчивые македонцы зарабатывают на Трампе. DW. 08.11.2016. URL: https://p.dw.com/p/2SK6A (дата звернення: 20.05.2021).

5. Панченко О.А. Информационно-психологическая безопасность в эпоху турбулентности: монография. К.: КВИЦ. 2020. 472 с. DOI: 10.5281/zenodo.3989790 ISBN 978-617-697-121-4.

6. Почепцов Г. (Дез)информация. Под общей редакцией Н. Лигачевой и Г. Петренко. К. : ПАЛИВОДА А.В., 2019. 248 с.

7. Указ Президента України від 7 травня 2021 року № 187/2021 «Питання Центру протидії дезінформації». URL: https://www.president.gov.ua/documents/1872021-38841.

8. About Truth Decay. RAND Corporation. URL: https://www.rand.org/ research/projects/truth-decay/about-truth-decay.html.

9. Bob Holmes. The pernicious contagion of misinformation. 10.02.2020. URL: https://knowablemagazine.org/article/society/2020/pernicious-contagion-misinformation (дата звернення: 20.05.2021).

10. Claire Wardle, Hossein Derakhshan. Information Disorder: Toward an interdisciplinary framework for research and policymaking. Council of Europe report DGI(2017)09. September 27, 2017. URL: https://rm.coe.int/information-disorder-toward-an-interdisciplinary-frameworkfor-researc/168076277c (дата звернення: 20.05.2021).

11. Claire Wardle. Understanding InformationDisorder. First Draft. October 2019. URL: https://firstdraftnews.org/wpcontent/uploads/2019/10/Information_Disorder_Digital_AW.pdf?x76701.

12. Disinformation and «fake news»: Final Report Eighth Report of Session 2017-19. URL: https://publications.parliament.uk/pa/cm201719/cmselect/cmcumeds/1791/1791.pdf (дата звернення: 20.05.2021).

13. Elisa Shearer. More than eight-in-ten Americans get news from digital devices. PEW RESEARCH CENTER. January 12, 2021. URL:https://www.pewresearch.org/fact-tank/ 2021/01/12/more-than-eight-in-ten-americans-get-news-from-digital-devices/ (дата звернення: 20.05.2021).

14. Facebook видалив мережу акаунтів, пов’язану зі «Слугою народу». Українська правда. П'ятниця, 7 Травня, 2021. URL: https://www.pravda.com.ua/news/2021/05/7/ 7292718/\#comments (дата звернення: 20.05.2021).

15. EU Code of Practice on Disinformation. 2018. URL: https://www.nrada.gov.ua/wpcontent/uploads/2019/09/1CodeofPracticeonDisinformation-1.pdf (дата звернення: 20.05.2021).

16. Frederic Filloux. More than 600 global brands still feed the fake news ecosystem. Monday Note. August 21, 2017. URL: https://mondaynote.com/more-than-600-global-brandsstill-feed-the-fake-news-ecosystem-d1ddfbd80458 (дата звернення: 20.05.2021).

17. Morris V. Grading Gerasimov: Evaluating Russian Nonlinear War Through Modern Chinese Doctrine/ Small Wars Journal. 2015. URL: https://web.archive.org/web/ 20151217191006/http://smallwarsjournal.com/printpdf/30157 (дата обращения: 20.01.2020). 
18. NEWS IN A DIGITAL AGE. Comparing the Presentation of News Information over Time and Across Media Platforms. 2019. RAND Corporation. URL: https://www.rand.org/pubs/research_reports/RR2960.html.

19. Threat Report The State of Influence Operations 2017-2020. Facebook. May, 2021 URL: https://about.fb.com/wp-content/uploads/2021/05/IO-Threat-Report-May-20-2021.pdf.

\section{References:}

1. Gerasimov V.V. (2013). Tsennost nauki v predvidenii [Gerasimov V.V. The value of science is in foresight]. Voyenno-promyshlennyy kuryer - Military industrial courier, 8 (476) [in Russian].

2. Yevrokomisiya prezentuvala kodeks protydiyi feykam. UKRINFORM. (2019). [The European Commission presented a code of counteraction to fakes. UKRINFORM]. www.ukrinform.ua. Retrieved from https://www.ukrinform.ua/rubric-world/2629474evrokomisia-prezentuvala-kodeks-protidii-fejkam.html [in Ukrainian].

3. Kolisnyk O.L., \& Plokhuta I.S., \& Tretyak S. D. (2021). Sotsialno-psykholohichni ta fenomenolohichni aspekty doslidzhennya problemy dezinformatsiyi u mizhosobystisnomu spilkuvanni [Socio-psychological and phenomenological aspects of the study of the problem of misinformation in interpersonal communication]. Visnyk Natsionalnoho universytetu oborony Ukrayiny - Bulletin of the National University of Defense of Ukraine (1 (59) (pp. 121-130) [in Ukrainian].

4. Mikhail Bushuyev. (2016). Kak predpriimchivyye makedontsy zarabatyvayut na Trampe [How enterprising Macedonians make money on Trump]. p.dw.com. Retrieved from https://p.dw.com/p/2SK6A [in Russian].

5. Panchenko, O.A. (2020). Informatsionno-psikhologicheskaya bezopasnost v epokhu turbulentnosti: monografiya [Information and psychological security in the era of turbulence: monograph]. Kyiv: KVITS [in Russian].

6. Pocheptsov G. (2019). (Dez)informatsiya. Pod obshchey redaktsiyey Ligachevoy N. i Petrenko G. [(Des)information. Edited by N. Ligacheva and G. Petrenko]. Kyiv: PALIVODA A.V. [in Russian].

7. Ukaz Prezydenta Ukrayiny (2021) № 187/2021 «Pytannya Tsentru protydiyi dezinformatsiyi». [«Issues of the Center for Countering Disinformation»] www.president.gov.ua. Retrieved from https://www.president.gov.ua/documents/1872021-38841[in Ukrainian].

8. About Truth Decay. RAND Corporation. Retrieved from https://www.rand.org/research/projects/truth-decay/about-truth-decay.html [in English].

9. Bob Holmes. (2020). The pernicious contagion of misinformation. Retrieved from https://knowablemagazine.org/article/society/2020/pernicious-contagion-misinformation [in English].

10. Claire Wardle, Hossein Derakhshan. (2017). Information Disorder: Toward an interdisciplinary framework for research and policymaking. Council of Europe report DGI(2017)09. Retrieved from https://rm.coe.int/information-disorder-toward-aninterdisciplinary-framework-for-researc/168076277c [in English].

11. Claire Wardle. (2019) Understanding InformationDisorder. First Draft. Retrieved from https://firstdraftnews.org/wp-content/uploads/2019/10/Information_Disorder_Digital_AW. pdf?x76701 [in English].

12. Disinformation and «fake news»: Final Report Eighth Report of Session 2017-19. Retrieved from https://publications.parliament.uk/pa/cm201719/cmselect/cmcumeds/1791/1791. pdf [in English].

13. Elisa Shearer. (2021). More than eight-in-ten Americans get news from digital devices. PEW RESEARCH CENTER. Retrieved from https://www.pewresearch.org/facttank/2021/01/12/more-than-eight-in-ten-americans-get-news-from-digital-devices/ [in English].

14. Facebook vydalyv merezhu akauntiv, povyazanu zi «Sluhoyu narodu». Ukrayinska pravda. (2021). [Facebook has removed the Network of People account. Ukrainian Pravda]. 
www.pravda.com.ua. Retrieved from https://www.pravda.com.ua/news/2021/05/7/7292718/\# comments [in Ukrainian].

15. EU Code of Practice on Disinformation. (2018). Retrieved from https://www.nrada.gov.ua/wp-content/uploads/2019/09/1CodeofPracticeonDisinformation-1.pdf [in English].

16. Frederic Filloux. (2017). More than 600 global brands still feed the fake news ecosystem. Monday Note. Retrieved from https://mondaynote.com/more-than-600-globalbrands-still-feed-the-fake-news-ecosystem-d1ddfbd80458 [in English].

17. Morris V. (2015). Grading Gerasimov: Evaluating Russian Nonlinear War Through Modern Chinese Doctrine/ Small Wars Journal. Retrieved from https://web.archive.org/ web/20151217191006/http://smallwarsjournal.com/printpdf/30157 [in English].

18. NEWS IN A DIGITAL AGE. Comparing the Presentation of News Information over Time and Across Media Platforms. (2019). RAND Corporation.

Retrieved from https://www.rand.org/pubs/research_reports/RR2960.html [in English].

19. Threat Report The State of Influence Operations 2017-2020. Facebook. (2021). Retrieved from https://about.fb.com/wp-content/uploads/2021/05/IO-Threat-Report-May-202021.pdf [in English]. 